\title{
Structuring cumulative effects assessments to support regional and local marine management and planning obligations
}

\author{
Edward A. Willsteed $^{1,2}$, Silvana N. R. Birchenough ${ }^{2 *}$, Andrew B. Gill ${ }^{1,3}$, Simon Jude $^{1}$ \\ ${ }^{1}$ School of Water, Energy and Environment, Cranfield University, Cranfield, Bedfordshire, MK43 0AL, UK \\ ${ }^{2}$ The Centre for Environment, Fisheries and Aquaculture Science (Cefas), Pakefield Road, Lowestoft, Suffolk NR33 OHT, UK \\ ${ }^{3}$ PANGALIA Environmental, Ampthill, Bedfordshire, UK MK45 2QX \\ *Corresponding author: silvana.birchenough@,cefas.co.uk
}

Declarations of interests: none

\begin{abstract}
Cumulative effects assessments are a legal requirement in many jurisdictions and are key to informing marine policy. However, practice does not yet deliver fit-for-purpose assessments relative to sustainable development and environmental protection obligations. The complexity of cumulative effect questions, which are embedded in complex social-ecological systems, makes multiple, methodologically diverse assessments a necessity. Using the expansion of marine renewable energy developments in European Union waters as a case study, this paper explores how social-ecological systems thinking and cumulative effects assessment theory can combine to structure CEAs that better support the management and regulation of maritime activities at regional scales. A general perspective for cumulative effects assessment is proposed to remove ambiguity of intent and to orient assessments towards a common objective. Candidate principles for practice are presented for consideration. These principles are integrated into a stepped assessment approach that seeks to improve cumulative effects assessments of localised activities relative to the information needs of decision-makers implementing the ecosystem approach.
\end{abstract}

\section{Highlights}

- Understanding and managing cumulative effects is fundamental to sustainable development and requires regional coherence between assessments oriented towards resolving a common issue. 
- A case is presented for structuring cumulative effects assessments using social-ecological systems thinking and a novel stepped approach is proposed to better support ecosystem-approach marine management.

\section{Keywords}

Cumulative effects assessment; cumulative impact; marine management; marine spatial planning; socialecological systems; ecosystem approach

\section{Introduction}

The magnitude and extent of human activities in the $21^{\text {st }}$ Century are a driving force shaping the dynamics and resilience of ecosystems [1]. These activities strongly influence the continuance or loss of ecosystem services and the resources that support societies and economies [2]. How resilient services and resources are to further disturbance, extraction or other use is influenced by the cumulative effects load (see Table 1) carried by those services and resources. Hence, there is growing interest in cumulative effects assessment.

Cumulative effects assessments or cumulative impact assessments (hereafter CEA; see Table 1) are a specific form of environmental assessment designed to provide information about how the effects of human activities contribute to environmental change [3]. The term CEA covers many forms of assessment over many temporal and spatial scales, but relative to environmental management, CEAs are often associated with formal environmental assessments [4]. Shortcomings of such CEAs are well cited and improved practice is urgently required to fulfil legal obligations and to support marine management and planning where degraded ecosystems support vital human activities and where future development is needed to support blue growth objectives [5].

Challenges to improved CEA are multidimensional, including bureaucratic (how to include CEAs in decision-making; [6], practical (better linking CEA theory and practice; e.g. [7], and scientific (e.g. how stressors cumulate; [8]; and which stressors matter most [9]). Ambiguity about the intent of CEA (though not of the driving legislation [10]) further hinders efforts to improve practice [10]. This paper seeks to remove ambiguity about the intent of CEA and to link procedural and scientific progress to advance CEA practice. This is also a multifaceted challenge, as unravelling a cumulative effect question, such as investigating the cumulative effect of one spatially localised development quickly points to a range of variables and scales becoming relevant (Figure 1). Further, the resilience (see Table 1) of ecosystem 
components (receptors) to additional stressors is dynamic, as the resilience of the receptor at the time is influenced by a spatially and temporally variable spectrum of stressors and processes [11,12].

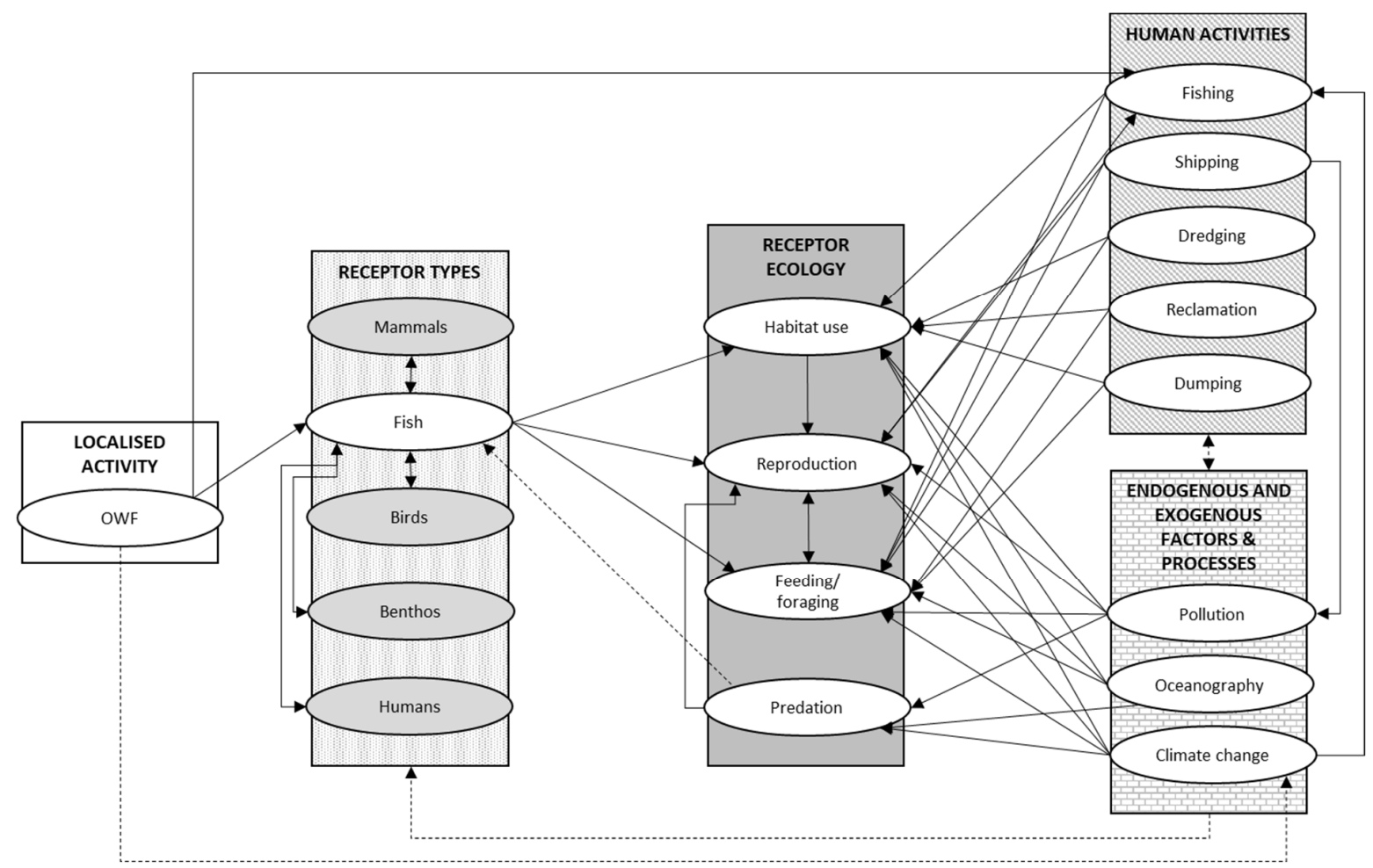

Figure 1. A non-exhaustive set of direct relationships identified when unpacking a cumulative effect question, such as what is the cumulative effect of one offshore wind farm (OWF) on one receptor type (fishes) within a social-ecological system representative of the Southern North Sea. Dashed arrows indicate feedbacks, such as endogenous and exogenous processes feeding back to influence receptors.

The receptor-led perspective [13] brings into consideration connectivity and varied temporal and spatial scales of pertinent processes, patterns and human activities. Varied ecological scales are involved and numerous scientific approaches are relevant, from laboratory studies to ecosystem models (see Hodgson and Halpern [14] for a review of academic CEA approaches addressing ecological scale). The spectrum of stressors acting on receptors tends to reflect a multitude of human activities, highlighting that cumulative effect questions are situated in coupled social-ecological systems (see Table 1). Human social components determine the effectiveness, or not, of management interventions [12] and are thus relevant to CEA. Investigating the interactions between such a range of components inevitably points to multiple interdisciplinary assessments employing multiple scales of inquiry. However, for such assessments to support marine management and planning requires CEAs that investigate the multitude of interactions and are structured so that knowledge from discrete assessments can cumulate. 
This paper uses the development and expansion of marine renewable energy (MRE) in European Union waters as a case study to examine why legislated obligations to assess cumulative effects of individual developments and of strategic plans pose complex scientific questions. Addressing these questions requires a balance between flexibility, structure and rigour to aid decision-making in an uncertain environment. Faced with climate change and the imperative to transition to sustainability (see Table 1), MRE can meaningfully contribute to a low carbon energy generation sector [15]. However, there is no consensus about how significant the environmental impacts of MRE are, leading to substantial uncertainties that delay development. Nevertheless, the spatial and temporal footprints of MRE are increasing as technologies scale up for commercial testing and as proven technologies are industrialised [5]. MRE developments overlap with existing marine users and introduce additional stressors and effects into marine ecosystems (Figure 1), ecosystems that have changed under a legacy of past human activities and continue to change under existing effects loads. Considering how MRE environmental effects change the resilience of marine ecosystems thus draws attention to critical components of cumulative effect questions, including scale, multiple variables and baselines.

Here, a case is presented for structuring CEAs intended to meet legislated obligations within a socialecological system framework and to orient CEAs to support one overall Strategic CEA, (shortened to SCEA), an ongoing regional environmental assessment process that reflects current knowledge about receptors and receptor resilience. The SCEA is intended to support local and regional decision-making processes by integrating information from CEAs, which may be stimulated by the need to fulfil project or strategic assessment obligations, guided by a common vocabulary and principles. Commonalities between diverse assessments are identified and a general perspective of CEA is proposed to remove ambiguity about the intent of assessments while maintaining flexibility of approach. Building on conventions proposed by Judd et al. [10], principles are advanced for consideration by regulators, scientists and practitioners, to support progress towards harmonised regional practice. In conclusion, a novel CEA approach is presented that intends to address shortcomings of Environmental Impact Assessment-led CEA.

Table 1. Glossary of concepts and terms

\begin{tabular}{|l|l|}
\hline Concept/Term & Definition \\
\hline $\begin{array}{l}\text { Cumulative effects } \\
\text { load }\end{array}$ & $\begin{array}{l}\text { The range of effects experienced by receptors that contribute to the overall health of a } \\
\text { receptor }\end{array}$ \\
\hline Sustainability & $\begin{array}{l}\text { Meeting "human needs now and in the future by continuously improving and balancing } \\
\text { environmental integrity, economic vitality, and social equity" (Wu [2]; pg 1012) }\end{array}$ \\
\hline $\begin{array}{l}\text { Ecosystem } \\
\text { Approach }\end{array}$ & $\begin{array}{l}\text { Recognising the connection between ecosystems and social systems, the Ecosystem } \\
\text { Approach requires management that protects and maintains ecological characteristics } \\
\text { while delivering the services and benefits required by society [16] }\end{array}$ \\
\hline
\end{tabular}




\begin{tabular}{|l|l|}
\hline $\begin{array}{l}\text { Social-ecological } \\
\text { systems }\end{array}$ & $\begin{array}{l}\text { Coupled systems of people and nature embedded in the biosphere, recognising humans } \\
\text { as an intrinsic part of nature [17] }\end{array}$ \\
\hline $\begin{array}{l}\text { Cumulative Effects } \\
\text { Assessment (CEA) }\end{array}$ & $\begin{array}{l}\text { A systematic procedure for identifying and evaluating the significance of human } \\
\text { activities on the resilience of social-ecological system components (receptors). }\end{array}$ \\
\hline $\begin{array}{l}\text { Strategic } \\
\text { Cumulative Effects } \\
\text { Assessment (SCEA) }\end{array}$ & $\begin{array}{l}\text { An ongoing process to which coherent, tractable CEAs contribute data and knowledge } \\
\text { about the effects of human activities on the persistence of relationships between } \\
\text { components of social-ecological systems to support adaptive management and } \\
\text { governance. }\end{array}$ \\
\hline Resilience & $\begin{array}{l}\text { A dynamic concept that refers to the persistence of relationships within a system, the } \\
\text { capacity of systems to absorb disturbance and reorganise while undergoing change, i.e. } \\
\text { to retain the same functions, structure and feedbacks to sustain identity [17,18] }\end{array}$ \\
\hline
\end{tabular}

\section{Specifying coherence for cumulative effects assessment}

First, the interpretation of coherence as applied to CEA is dealt with. CEAs originated from Environmental Impact Assessment (EIA) legislation revised to oblige EIAs to assess the cumulative effects of development on the environment [19]. In the European Union, CEA is also required at the strategic level as well as the project level, and in relation to protected habitats and species. Thus, assessments that in one form or another assess cumulative effects provide information to decision-makers in relation to licensing, consent and monitoring of individual developments; dispersed activities such as commercial fishing; protected areas; and regional obligations to promote sustainable use of the seas (Figure 2). 


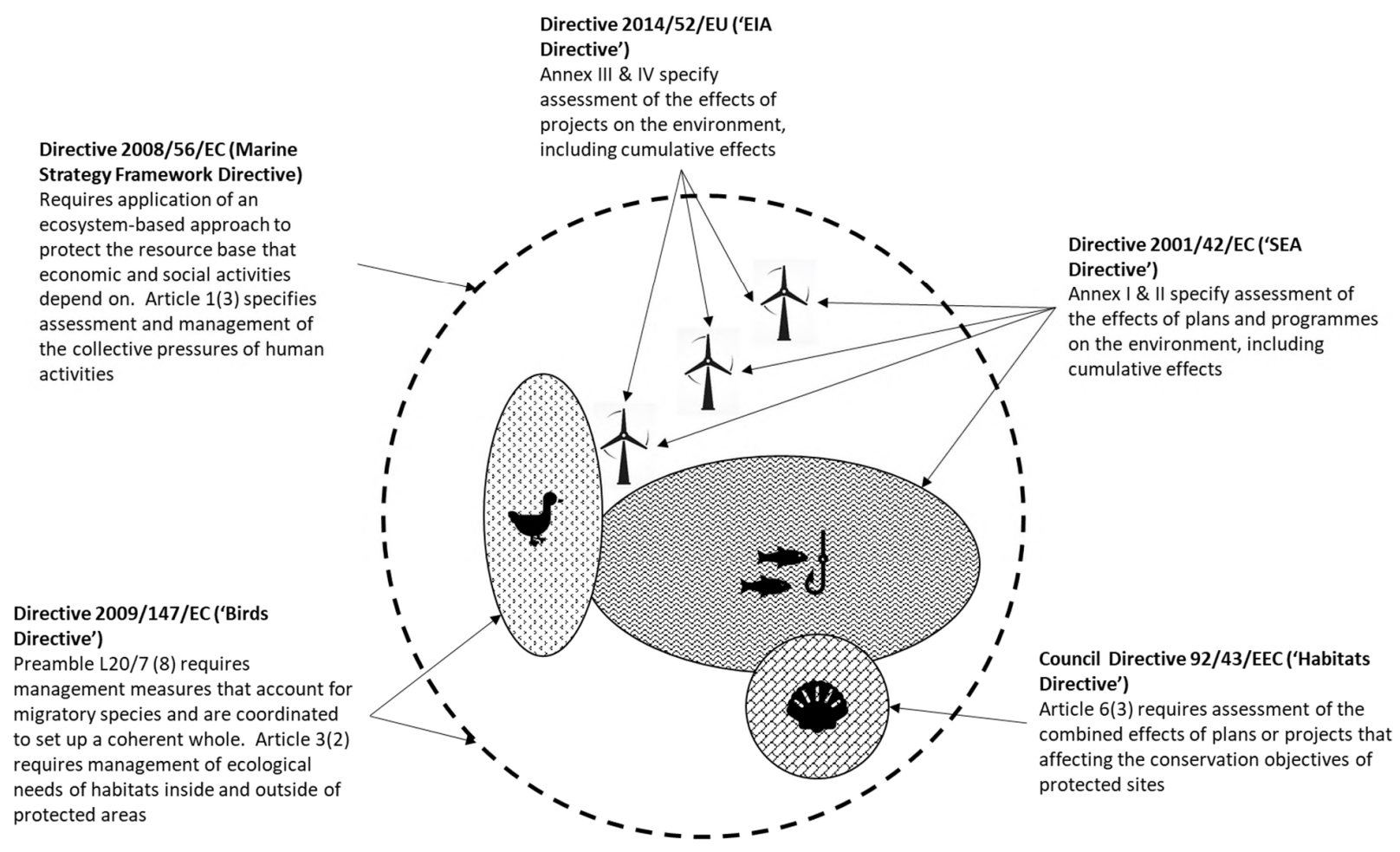

Figure 2. A representation of a social-ecological system within which are different activities and valued receptors, each of which is subject to one or more assessments that each contribute to the knowledge base of cumulative effects in a system.

While the terminology behind the respective EC Directives driving these assessments is not synonymous, these assessments seek to address the same underlying issue of environmental change caused by cumulative effects. At present, pertinent information is often scattered between incomparable assessment outputs, but knowledge cumulation requires systemic consistency and the integration of diverse elements into a greater whole, i.e. coherence. This is a multifaceted challenge, as CEA is not a monolithic concept and can be applied to decision-making in different ways. At its root, CEA seeks to prevent the depletion and loss of valued resources and ecosystem services. Managing cumulative effects requires analyses of the multitude of effects acting on resources and ecosystems at different scales. Coherence thus implies systemic consistency between CEAs focussed on different scales of assessment and variables within a system, but this consistency is often not found in practice [20].

On the other hand, the complexity of cumulative effects works against standardisation [4]. Complex problems need to maintain diversity and flexibility of approach and discourse [17] and current legislation requires different CEAs for different purposes [10]. Coherence therefore needs to balance consistency with the flexibility required to enable methodological pluralism and interdisciplinary research. This overview is set against a reality constrained by budgets, legislation, and the need to produce timely 
assessments to ensure license applications for MRE developments that are widely viewed as an important component of a (hopefully near) future are not unduly delayed. Hence coherence involves trade-offs between pragmatism, a desire for greater certainty about effects, and the need to conduct narrow - in a systems sense - assessments to fulfil specific obligations.

\section{Social-ecological systems and cumulative effects assessment}

\subsection{Implications for cumulative effects assessment}

Human activities, influential in marine ecosystems worldwide [21,22], are coupled with ecosystem services and resources in social-ecological systems [23]. Social-ecological systems are complex adaptive systems where processes and components dynamically interact at different and linked temporal and spatial scales, where feedback loops play a defining role in influencing system behaviour, and where interactions tend to be non-linear $[1,12]$. Localised changes can cumulate to cause slow, broad-scale change that in turn affect local processes and patterns via feedback loops [12]. Interactions between system components evolve over time and have a self-organising capacity, and unpredictability and uncertainty are intrinsic to complex adaptive systems [2] (and hence are inherent in CEA).

The characteristics of complex adaptive systems give rise to management and policy challenges relevant to CEA. Local actions scaling up to effect change at higher scales that then feedback typically lead to slow structural change in the ecosystem over long time periods up to the point where abrupt changes occur that may be irreversible [12]. Determining how significant past effects have been and predicted effects will be on ecosystems is complex, and will depend on the system's or component's capacity to recover and/or reorganise following a disturbance [24]. The predominant approaches employed in environmental assessments to investigate these relationships tend to be linear [25] and reductionist [26]. Diverse sustainability issues are reduced to a small set of variables and make use of singular indicators, dimensions (e.g. economic, social or environmental), limited scales of analysis and narrow time horizons [26]. Linear, reductionist approaches are user friendly, but risk giving misleading representations of system dynamics that could lead to ineffective or counterproductive governance interventions being developed [12].

Social-ecological systems thinking offers real support to CEA, by drawing attention to the characteristics of complex adaptive systems. The variable temporal and spatial scales and many components involved point to the need to facilitate continual learning informed by multidisciplinary studies [12,23]. One practical step to enable continual learning would be for regulators and CEA/EIA practitioners to commit to using common language across assessments and to structure assessments to deliver comparable outputs 
across the spectrum of human activities. Without a means of structuring and organising the variables and outputs from studies investigating the variables within a system, knowledge from diverse assessments seeking to address a common issue remains isolated.

\subsection{Social-ecological frameworks as structuring objects}

Social-ecological systems research has led to the development of structuring objects designed to identify and analyse relationships between multiple levels of complex systems nested at different spatial and temporal scales [23]. Different frameworks exist that differ in terms of how relationships between social and ecological components are conceptualised, whether an anthropological or ecological perspective dominates, and whether outputs are action or analysis oriented [27]. Whether one specific framework could be appropriate for facilitating coherent CEA in a region requires testing, but here Ostrom's framework [23] is highlighted, which has been applied to diverse resource management settings, including in the marine realm (e.g. [28,29]).

Ostrom's framework was developed to provide a theory-neutral framework to support interdisciplinary analyses of the determinants of sustainability in complex social-ecological systems, with the intended application to well-defined domains of common-pool resource management situations [30]. Pertinent to CEA coherence, the framework establishes a common vocabulary and structure from which to construct and test alternative theories and models to determine which influences on processes and outcomes are critical in specific empirical settings [30].

While the framework treats social and ecological components equally [27], it has been criticised for not sufficiently including the role of biophysical characteristics and ecological processes in diagnosing the sustainability of social-ecological systems [31]. Epstein et al. [31] proposed the addition of ecological rules as a first-tier component (i.e. of equal importance to other first-tier components) to better account for ecological processes shaping social-ecological system sustainability. With continuing modification and formalisation (e.g. [32]), such a framework may lead to a structuring object and language that can facilitate systematic and coherent analyses of disparate social-ecological system variables to investigate interactions and outcomes at local and regional levels.

\subsection{Changing resilience as a measure for cumulative effects assessment}

Resilience is a common lens of inquiry that has emerged in social-ecological systems thinking since Holling's seminal 1973 paper, as an approach to support interdisciplinary research investigating socialecological systems sustainability [1]. Resilience describes the persistence of relationships within 
ecosystems after disturbance and is a measure of an ecosystem's capacity to absorb environmental change and still persist [33]. Relationships between species and habitats, functions and processes collectively determine the abundance and continuance of resources, and are thus highly relevant to sustainable development. Human activities that disturb interactions between biotic and abiotic processes contribute to a loss of resilience that increases the likelihood of a shift to alternative states [21]. A system collapse can result in irreversible loss of social-ecological capital [34], though state change may be desirable if shifting from a degraded system to a more desirable one [35].

The resilience concept integrates consideration of spatial and temporal dynamics of social-ecological systems, encouraging movement away from the shifting baseline phenomenon that affects many environmental assessments [36], including formal CEAs [20]. Change in resilience is a compelling conceptual metric for CEA, but application remains vague [33]. Information on how a system and/or system components may respond to disturbances requires insights into variables with slow and fast dynamics. Slow variables tend to define system structure but resilience tends to be discussed in terms of perturbations that affect faster variables [37]. However, slight changes in slow variables may have a profound effect on the resilience of a system or receptor to absorb further perturbations [37].

Selecting metrics and indicators that can monitor and communicate how human activities individually and cumulatively influence resilience is an ongoing area of research [17], which in part reflects the varied conceptions of what resilience is and thus how it is defined, assessed and measured [33,38]. In the context of CEAs, the significance of additional disturbance to a receptor and hence to a social-ecological system, will reflect the status of the receptor at the time (Figure 3). CEAs, then, need to consider how resilient a receptor currently is and how big a change will occur in receptors following exposure to additional disturbance (resistance; [33]). Considering resilience and resistance aids identification of the magnitude of disturbance that a receptor can absorb before the persistence of relationships between the receptor and the broader system are overwhelmed. Identifying how a system or component has changed over time can provide insight into how precarious a system or component is, whether close to or distant from a boundary of attraction [35]. This temporal element is vital to CEA, particularly for CEAs seeking to identify how significant the introduction of additional stressors may be at a particular point in time. 


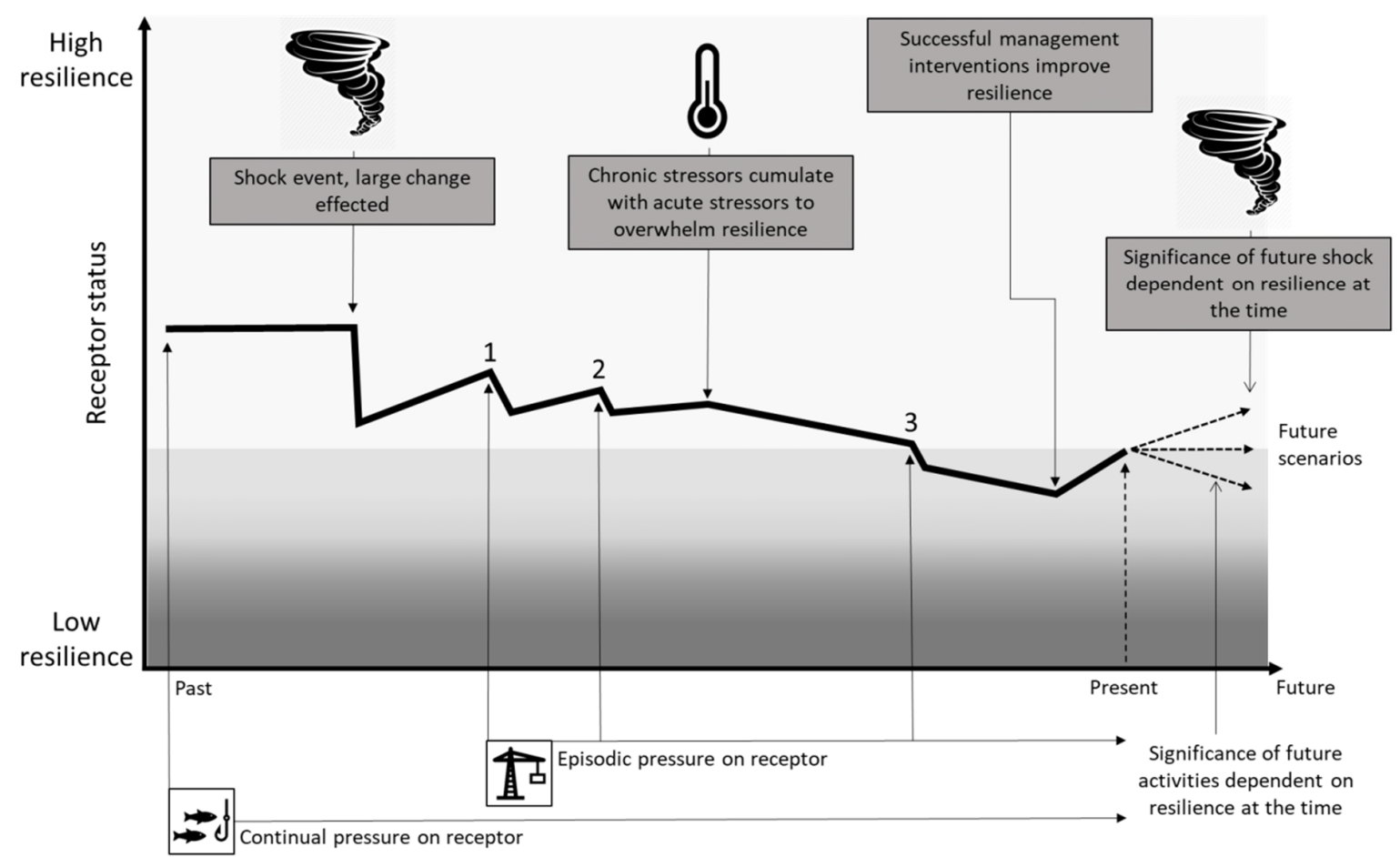

Figure 3. Change in the resilience of a valued receptor over time caused by individual activities and events, as the receptor recovers, and as the effects of human activities and natural events cumulate to overwhelm resilience. The significance of stressors is dependent on the resilience of the receptor at the time. Point 1 on the line shows a development causing a decline in the status of the receptor, which then enters a recovery period. Due to improved mitigation measures, a similar development has a reduced effect on the receptor (point 2). At point 3, a similar development has greater significance, as the receptor is less resilient to disturbance and requires management interventions to recover. The graduated colours associated with low resilience represent the increasing risk of the identity of the system changing.

Metrics are thus required that are able to detect the strength and direction of effects on receptors and which are able to account for the time lags that are often present between a stressor being introduced and the emergence of effects [39]. Typical metrics, such as species richness, can miss impacts of anthropogenic stressors on the persistence and hence resilience of critical ecological features (e.g. food webs; [40]). Hence there remains a search for metrics and indicators that are better able to provide insight into the dynamics and interactions between receptors and their environments, and between system components that contribute to resilience [17,41]. Whatever measures are chosen, they should be relevant to outstanding management questions, ideally would be empirically quantifiable and need to be tested over a range of temporal and spatial scales [42]. Key, also, is clarity within assessments about what is being measured relative to what effects, and at what temporal and spatial scales [37], particularly as the scale at which a phenomenon is studied can lead to different interpretations of what is influencing the dynamics of species and communities [43]. 


\section{$4 \quad$ A general perspective of cumulative effects assessment}

To address the ambiguity that hinders consistent CEA practice, a general perspective of CEA is advanced based on commonalities between CEAs completed in a region. Different legislation places different demands on specific assessments, but, as established, meeting regional and project-level obligations to account for cumulative effects requires coordination between multiple CEAs. The aim here is to foster debate about the levels at which commonalities between CEAs can be identified to support coherence of outputs independent of legislative drivers, without impinging on the flexibility needed to address cumulative effect questions.

Figure 4 illustrates a series of tiered concepts nested beneath an overarching objective to support the sustainability of a social-ecological system (tier one). Sustainability is dependent on sustainable development (the original purpose behind CEA; [44]) being realised and maintained (tier two). For CEA to contribute efficiently to sustainable development requires coherence between assessments that seek to identify and understand cumulative environmental change, which is rooted in phenomena beyond the capacity of individual assessments to investigate. This requires a common conception of cumulative effects to be established (tier three), which, it is suggested here, is already well defined (e.g. [19]). The intent hereafter is to advance tiers four (a general perspective of CEA) and five (guiding principles).

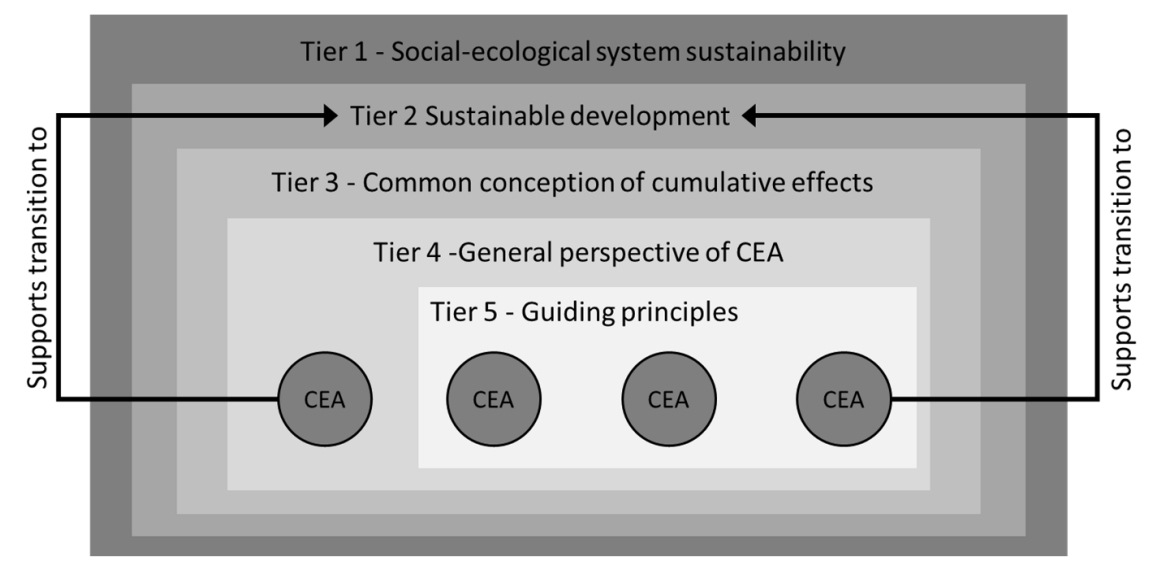

Figure 4. A tiered approach to identifying a general perspective of CEA that shares a common conception of cumulative effects and an overarching intent to support a transition to sustainable development. CEAs not applying guiding principles can apply the same intent to advance regional sustainable development.

The general perspective of CEA (tier four and Figure 5) is a conceptual reference point to guide CEA practice. It is generic to avoid conflicting with practical requirements linked to specific legislation. While generic, without an explicit perspective, ambiguity about intent may persist. Guiding principles (tier five and discussed in section 5) provide practical assistance for practitioners and marine regulators, and are intended to support the elaboration of specific CEA approaches that can be applied to, for 
example, project-level CEAs to better account for characteristics of social-ecological systems and cumulative effects, and where shortcomings continue to be identified (e.g. [20,45]).

The general perspective of CEA (Figure 5) seeks to account for the dynamism and multiple scales stressed in CEA theory and ecological theory, but not apparent in CEA practice. The dynamic relationship between ecosystem services and human wellbeing points to CEA being an ongoing need to support strategic and localised decision-making about current and proposed human activities relative to management objectives. The term Strategic CEA (SCEA) becomes important, to refer to an ongoing plan of management process that applies to a region and which evolves with information from discrete CEAs and which can support CEAs with baseline information about receptors. Via a commitment by regulators and practitioners to a common language and consistency, CEAs support the SCEA with assessments of cumulative effects arising from the spectrum of maritime activities present in the region interacting with valued receptors. This iteration and accumulation of knowledge is essential where management and policy formulation must make do with low-resolution evidence and need to be able to respond to unexpected change and revised ratings of system or system component resilience [1].

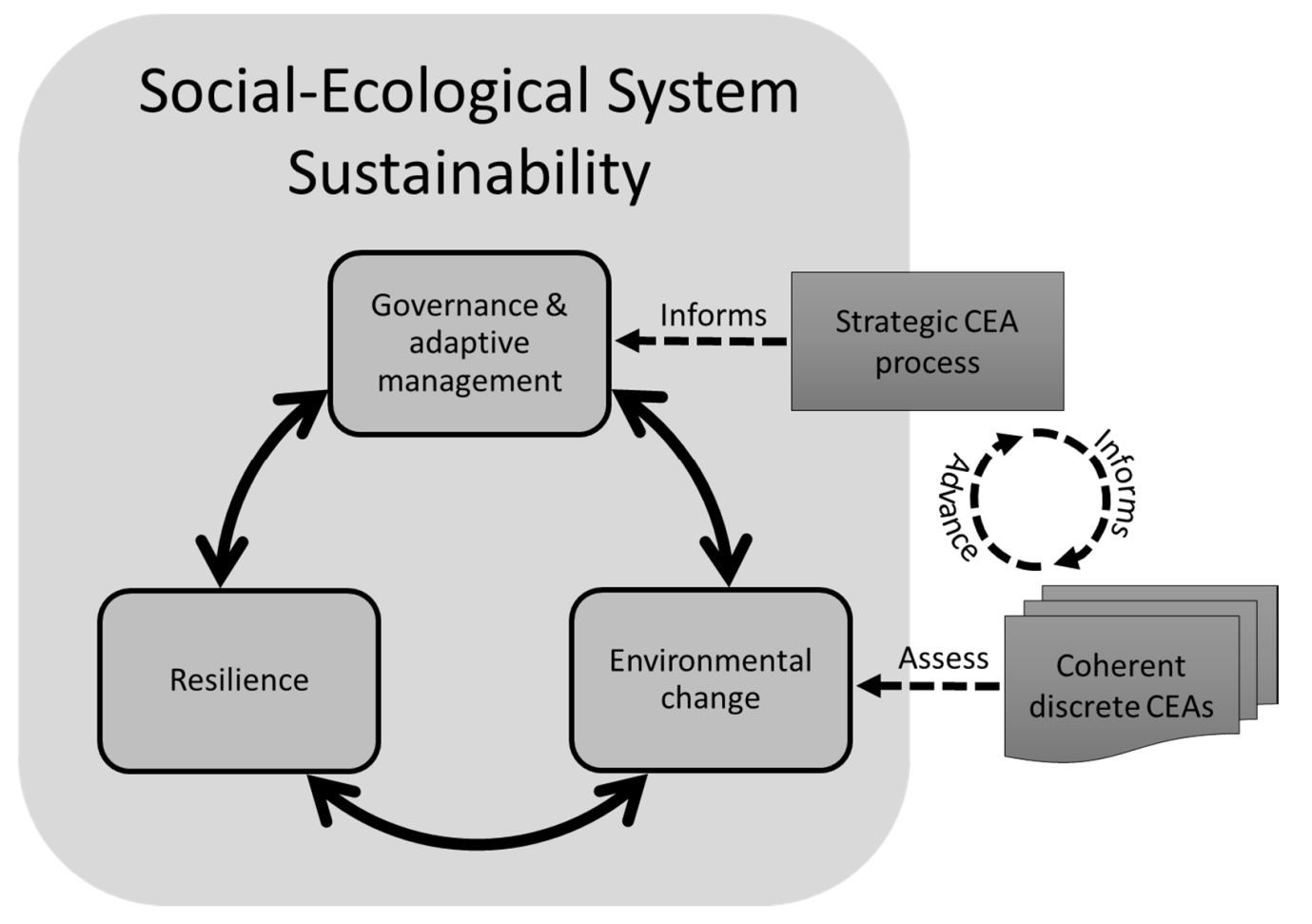

Figure 5. A general perspective of cumulative effects assessment as an ongoing decision-support process. The Strategic CEA (SCEA) is advanced by information from multiple coherent assessments investigating change in components of the system. The SCEA informs regional and local decision-making with advancing knowledge about the cumulative effects of human activities on the resilience of the system. A 
feedback loop between the SCEA and discrete CEAs (e.g. project/activity CEAs) indicates the mutually reinforcing flow of information.

The sustainability of a social-ecological system is linked to three interlinked aspects: i) the scale, rate and trajectory of environmental change occurring within the system [3,17]; ii) how resilient the system is [17]; and, iii) the adaptive capacity of society, through governance, to manage and influence change [35]. Sustainability requires specification of what is to be sustained, what is to be developed, the relationship between the two, and what scales are applicable [2]. The SCEA/CEA approach can support specification of these parameters through assessments of the accumulated state of the environment, developing appropriate baselines for monitoring and planning, and by developing future scenarios to explore the implications of current trajectories and trade-offs [46].

\section{Candidate principles and a stepped approach to assessment}

\subsection{Suggested principles for coherent practice}

Judd et al. [10] explored the principles and definitions underlying CEA and found inconsistent language, interpretation and parameterisation prevent scientifically more robust CEA approaches from effectively supporting marine management and policy-making. A recent review of regulators' experience with the EIA Directive in UK waters reiterates the need for improved consistency of and guidance for cumulative effects assessments [47]. To reduce ambiguity, Judd et al. [10] specify vocabulary for CEAs irrespective of driver and provide a set of recommended conventions for developing CEA methodologies. Here, these conventions are adapted and integrated with additional references to suggest principles for CEA practice (Table 2).

Table 2. Suggested principles for CEA practice based on recommended conventions in Judd et al (2015) and CEA/Social-ecological systems theory as referenced.

\begin{tabular}{|l|l|}
\hline Principle & Synopsis \\
\hline 1. Apply a cumulative mindset [48] & $\begin{array}{l}\text { Assessments of the current condition and resilience of valued social- } \\
\text { ecological system components seek to understand relative contributions } \\
\text { of the spectrum of stressors/effects. Recognise that future cumulative } \\
\text { effects may overwhelm resilience and require trade-offs and } \\
\text { rebalancing of cumulative effects loads to avoid impacts/support } \\
\text { recovery. }\end{array}$ \\
\hline $\begin{array}{l}\text { 2. Apply a social-ecological systems } \\
\text { mindset }[12,18]\end{array}$ & $\begin{array}{l}\text { Characteristics of social-ecological systems should feature in } \\
\text { management planning and policy-making. Non-linear interactions are } \\
\text { the norm not the exception, requiring appraisal of how effects may } \\
\text { cumulate. Qualitative views of system behaviour are valid and } \\
\text { valuable. }\end{array}$ \\
\hline $\begin{array}{l}\text { 3. Apply common vocabulary } \\
{[10,23,30]}\end{array}$ & $\begin{array}{l}\text { Consistent vocabulary is necessary to make greater use of varied CEA } \\
\text { approaches across marine management scales and purposes and to }\end{array}$ \\
\hline
\end{tabular}




\begin{tabular}{|c|c|}
\hline & $\begin{array}{l}\text { enable knowledge to cumulate to aid management of social-ecological } \\
\text { systems. }\end{array}$ \\
\hline $\begin{array}{l}\text { 4. Apply formalised environmental } \\
\text { risk assessment principles [10] }\end{array}$ & $\begin{array}{l}\text { Risk assessment principles enable scientifically defendable decision- } \\
\text { making when faced with low-resolution evidence and where there is } \\
\text { considerable uncertainty about the effects of decisions on management } \\
\text { objectives. Judd et al. [10] specify a four-step framework, elaborated } \\
\text { upon by Stelzenmüller and colleagues [49], also. ISO 31000:2018 } \\
\text { provides an internationally recognised standard for appropriate } \\
\text { consideration and management of risk. }\end{array}$ \\
\hline $\begin{array}{l}\text { 5. Link effort expended to risk of } \\
\text { significant environmental change [50] }\end{array}$ & $\begin{array}{l}\text { Link effort to risk, helping to focus on priority questions and receptors } \\
\text { relative to management objectives and a transition to sustainability } \\
\text { (mindful that legally unprotected species or functional groups may be } \\
\text { more effective indicators of system change). }\end{array}$ \\
\hline $\begin{array}{l}\text { 6. Assess a specific cumulative effect } \\
\text { question }[10,50]\end{array}$ & $\begin{array}{l}\text { Clearly formulate the problem and specify the elements/variables } \\
\text { included and the purpose of the assessment. }\end{array}$ \\
\hline $\begin{array}{l}\text { 7. Analyse pathways to refine } \\
\text { variables to include }[10]\end{array}$ & $\begin{array}{l}\text { Use a conceptual pathway model (e.g. Source-Stressor-Effect-Pathway- } \\
\text { Receptors) to define and refine variables included in CEAs and to } \\
\text { document the reductionist process. }\end{array}$ \\
\hline $\begin{array}{l}\text { 8. Transparency about parameters } \\
\text { selected for inclusion and the } \\
\text { treatment of uncertainties and } \\
\text { assumptions }[10,51]\end{array}$ & $\begin{array}{l}\text { The many uncertainties involved make structured and rigorous } \\
\text { documentation of CEA processes, assumptions and uncertainties } \\
\text { necessary, from start to finish. Skinner et al. [51] provide a typology of } \\
\text { uncertainties designed to support risk characterisation. }\end{array}$ \\
\hline $\begin{array}{l}\text { 9. Integrate time into assessments } \\
{[2,10,19,37,50]}\end{array}$ & $\begin{array}{l}\text { Short-term and long-term dynamics are critical components of social- } \\
\text { ecological system sustainability. Assessing change in resilience, } \\
\text { regardless of definition, has a temporal component, requiring } \\
\text { measurement of at least two points in time. CEA theory is clear that } \\
\text { CEAs should include time. }\end{array}$ \\
\hline $\begin{array}{l}\text { 10. Focal receptor life history } \\
\text { characteristics set assessment } \\
\text { boundaries }[13,52]\end{array}$ & $\begin{array}{l}\text { Ecosystems and ecological receptors experience an array of } \\
\text { anthropogenic stressors in addition to natural perturbations, the effects } \\
\text { of which cumulate and interact over different spatial and temporal } \\
\text { scales relative to each receptor. Receptors are the crux of CEA, as they } \\
\text { experience a spectrum of stressors/effects that cumulate to have a net } \\
\text { effect on the receptor. Receptors provide context and rationale for } \\
\text { boundaries and baselines. }\end{array}$ \\
\hline $\begin{array}{l}\text { 11. Account for known variables that } \\
\text { contribute to the condition of focal } \\
\text { receptors [50] }\end{array}$ & $\begin{array}{l}\text { Assessments of the incremental and net effects (i.e. the cumulative } \\
\text { effects) of anthropogenic stressors on receptors and hence on ecosystem } \\
\text { structure and functioning should include consideration of variables that } \\
\text { influence receptor condition. As well as anthropogenic effects, } \\
\text { biophysical processes and disturbances are influential. }\end{array}$ \\
\hline $\begin{array}{l}\text { 12. Assess change in the resilience of } \\
\text { focal receptors/variables caused by } \\
\text { effects associated with the guiding } \\
\text { question }\end{array}$ & $\begin{array}{l}\text { Marine ecosystems and receptors experience several types of } \\
\text { disturbances. Resilience may vary depending on the type of } \\
\text { disturbance, the magnitude and footprint of effects arising from the } \\
\text { disturbances. How resilience responds to additional disturbance } \\
\text { requires a sound understanding of cause-effects relationships of } \\
\text { receptors/variables. }\end{array}$ \\
\hline
\end{tabular}

\subsection{A candidate approach to cumulative effects assessment}

Building on the principles above, a cumulative effects assessment approach is presented (Figure 6) that integrates the general perspective and suggested principles, and which seeks to improve CEA practice for localised activities in prospective scenarios. The intention here is to set out a series of steps that 
individually and collectively can be investigated, adapted and formalised to support the development of future guidelines for practitioners and regulators. This would allow practitioners and regulators to address project-level CEA shortcomings relative to ecosystem approach, an area where progress is necessary [20]. 


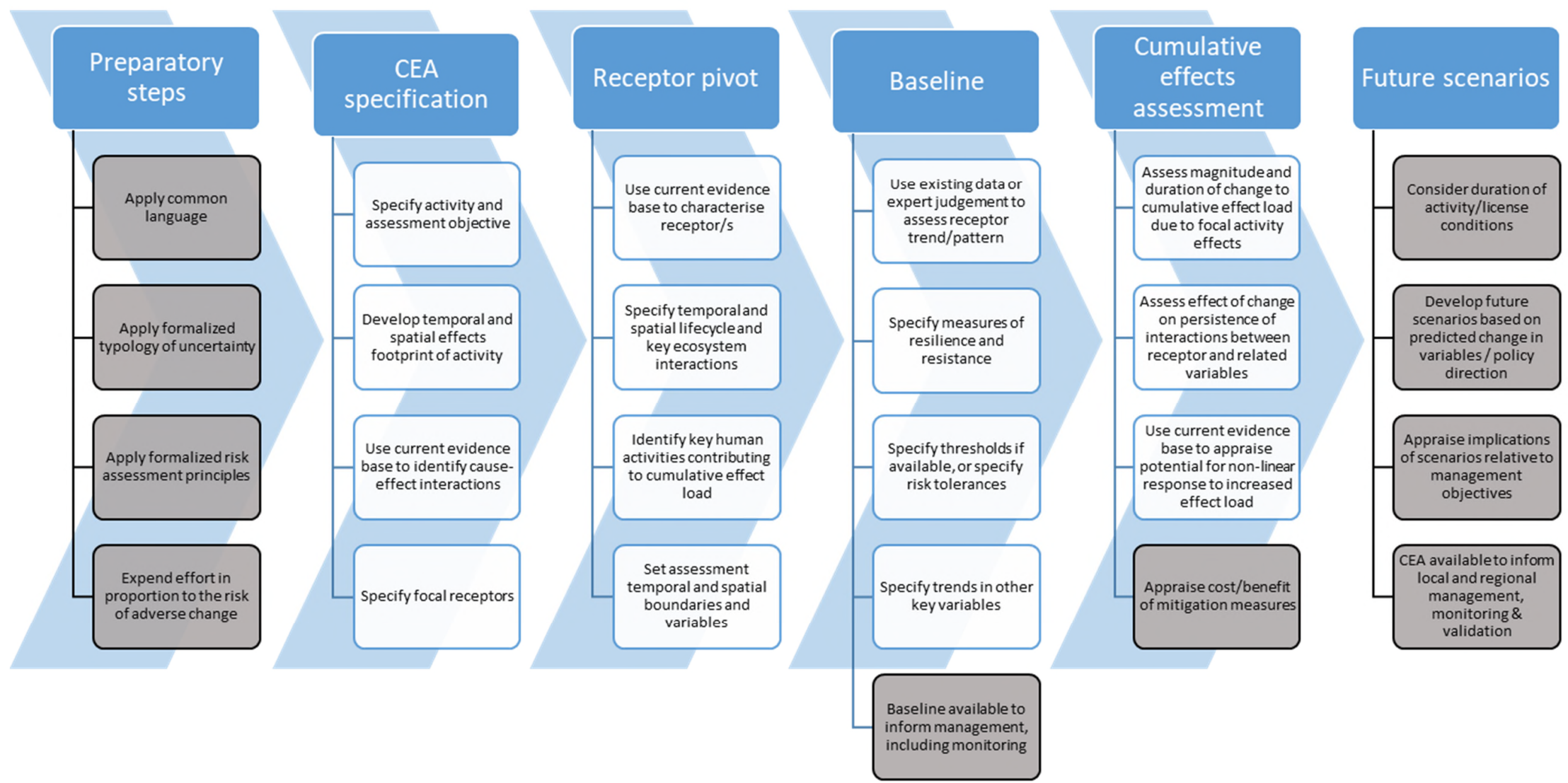

Figure 6. A stepped approach to CEA intended to enable assessments that meet EIA obligations to better account for cumulative effects. The approach comprises a series of 6 processes that are completed iteratively to assess the risk that a development or activity may impact the persistence of relationships between valued receptors and social-ecological systems, contributing to a decline in system resilience. In practise, the approach may be less linear, with subsequent steps stimulating iterations of preceding steps. Preparatory steps establish coherence between individual CEAs and apply throughout the approach. Steps highlighted grey are those where regulatory involvement and leadership is envisaged as necessary. The completed baseline is highlighted as being of use to the Strategic CEA, as well as subsequent project/activity CEAs where interactions with the same focal receptors are identified. 
The approach posited builds upon social-ecological systems and CEA theory, and the authors' experience with CEAs. The intention has been to argue the case for coherent CEA practice framed by socialecological systems theory and CEA theory, and to present an approach that is recognisable to existing practitioners and regulators. Clearly, this requires testing with real-world scenarios to see how the theory holds in practice. Briefly, the approach and theoretical advantages relative to EIA-led CEA are highlighted.

The preparatory process lays the ground for coherence between CEAs. The grey highlighted steps within the preparatory process (and elsewhere in Figure 6) are steps where regulatory leadership is recommended, for example to ensure the language and approach to environmental risk are consistent with regulatory information needs and management objectives. The specification process seeks to identify the spatio-temporal footprint of effects of an activity that via a pathway of effects model can be linked with known receptors that are sensitive to the activity effects generated and likely to be exposed.

The CEA approach then pivots around the receptor to integrate the receptor-led approach [48]. Receptors guide specification of temporal and spatial boundaries recognising that proportionality relative to the activity proponent and 'good enough' [19] will come into play, as migratory and wide-ranging species, or poor data resolution influence what is reasonable relative to the scope of project-level CEA. For example, a CEA completed by a project proponent that identifies focal receptors should include wideranging, migratory species could argue that it is reasonable that the proponent receives support to establish an understanding of the cumulative load carried by such species, or that the spatial boundaries of the assessment are limited. This receptor pivot process seeks to progress EIA-led CEA by putting into practice the broader spatial and temporal boundaries called for by CEA theory $[7,19,44]$ and to provide the CEA with a better base in terms of describing the spatial and temporal distributions of receptors and the underlying patterns.

The receptor pivot process also brings in consideration of the interactions between receptors and other system components (such as processes and activities) contributing to the cumulative effects load carried by a receptor. The intention is to ease away from environmental assessment approaches that are too linear in approach and which limit insights into system interactions [25]. Proportionality relative to the scope of a CEA is again a pertinent question. Slow changing variables and activities that influence the resilience of receptors to disturbance may be well beyond the standard temporal and spatial boundaries considered. Such variables should not be excluded without due consideration, however, given the importance these may have on the resilience on receptors and ecosystems to anticipated and future disturbance. Insights into the relationship between abiotic processes and receptors can also provide guidance about the 
suitability of existing datasets to reflect expected natural variability and sensitivity to human disturbance $[50]$.

The steps included in the baseline process seeks to establish a baseline that halts the scourge of sliding baselines in project-level assessments. Where data are available or can be collected to discern insights into receptor status and trends (e.g. [53,54]), assessments will be better able to qualify the risk additions to the cumulative effects load posed to receptors and hence on the resilience of the connected system. Thresholds are frequently referenced in CEA literature as vital (e.g. [7]), thresholds in practice are limited and decisions frequently need to be made without recourse to information about thresholds of disturbance $[33,55]$. In the absence of thresholds, formalised risk management processes, such as ISO 31000, can support evidenced specification of tolerance to risk relative to defined objectives, such as achieving good environmental status or maintaining a minimum population level.

The CEA process within the overall CEA approach is the area of greatest uncertainty and where the development of future regulator and practitioner guidance will need to keep abreast of emerging research and to maintain flexibility to enable methodologies applying to different scales of organisation to be integrated. CEA research is a rapidly evolving field and novel methodologies addressing interactions between activities and system functions are emerging (e.g. spatio-temporal effects of environmental drivers and fishing on food webs [56]). CEA approaches are available that provide explicit guidance to deal with the uncertainty inherent in CEA to derive evidenced risk-based outcomes [49]. Numerous relevant methodologies seek to identify cumulative effects operating at different biological and ecological scales (reviewed in [14]. Furthermore, experimental research into interactions between stressors and receptors continues to provide critical insights into the prevalence of nonlinear responses and system feedbacks [57,58]. Recent advances in modelling and statistical analysis are also enabling large datasets to be analysed to identify hierarchies of stressors influencing receptors [9,59]. The key to making the most of the plurality of methods is to establish systemic coherence relative to agreed objectives.

Relative to planning and managing individual activities and developments, a key outstanding question is the capacity to identify the influence of individual and grouped developments and activities on receptor/system resilience (or other metrics). Where the need to answer a CEA question dictates that progress be made quickly and where uncertainties are hazardous, risk-based approaches (e.g. [10,49]) become essential. Clarity and transparency within the CEA process are equally important and assumptions about the weight of focal activity effects relative to other activities and of the potential for non-linear effects should be specified and documented by CEA practitioners. Regulatory input is recommended to enable consistent approaches to weighting across sectors and activities. Incorporating formalised risk-based approaches with expert opinion can also yield robust advances for CEA faced with 
uncertainty [60]. Recognising that there are a multitude of ways to undertake CEA, the advance that the CEA approach shown in Figure 6 offers is the establishment of the broader context, from committing to a common language, to specification, to pivoting assessments around valued receptors and establishing an appropriate baseline prior to considering the consequences of a change in cumulative effect load.

The final steps, future scenarios, appraising management, monitoring and validation implications, require strategic oversight to aid coherence. A regional perspective is required to make best use of future scenarios, which are an underused resource for EIAs [61] and for exploring consequences of different courses of planning and strategic direction $[62,63]$. Formal approaches to scenario development are well established [61] and regional scenarios may support communication efforts to gain political and public commitment to sustainability by providing evidenced alternative future scenarios where trade-offs can be explored. The end-point of an individual CEA is determining significance, whether the risk posed to receptors and system components by a development or activity is acceptable relative to defined objectives. This, it is suggested here, should be for regulators to determine mindful of ecological integrity, economic vitality, and social equity.

\section{Moving forward}

This paper argues that a plurality of approaches is necessary to measure and manage cumulative effects due to the complexity of social-ecological systems. However, disparate CEAs need to be organised if obligations under regional (e.g. MSFD) and project-level (e.g. EIA) legislation are to be met meaningfully. The authors recognise that much of what is posited in this paper is hypothetical at this time. However, it is grounded in CEA theory and recent research highlighting the need to better match CEA practice with current science, and the imperative to account for cumulative effects that risk disrupting ecosystem services.

The interpretation of SCEA and the stepped CEA process will need to be supported by targeted future research. Testing the stepped approach needs to occur at different spatial and temporal scales, against real-world cumulative effect scenarios to investigate the role of boundaries, dynamics and relationships between system components, and between exogenous and endogenous components. The potential for social-ecological systems frameworks to act as structuring objects for CEA need to be put into practice, including exploring coherence between outputs of assessments aimed at different CEA questions. Testing measures of the resilience of system components will require studies to link outputs to the broader status of a social-ecological system and improving current knowledge about recovery and lags following the release of anthropogenic stressors. Deciding what an appropriate baseline is and how precarious 
components in a CEA are will require testing to check the influence of time periods on how significant cumulative effects of activities appear relative to the baseline adopted. Given the cumulation of effects, marine management and planning will need support characterising the weight of effects on the cumulative condition of receptors and to inform the need for license conditions for specific activities. Empirical studies are necessary to test the data needs of CEAs, including the usefulness of existing data at delivering the desired spatial and temporal resolution relative to identified indicators. Complexity is a common thread running through CEA and social-ecological systems discourse. Unravelling cause-effect networks that have a significant, residual effect on resilience requires research on relationships, feedbacks and various scales at which effects act on systems. The dynamic nature of systems raises a question about how to integrate CEA into both strategic and project-related management processes. Coordinating data collection, including baseline, monitoring and validation studies, is clearly an issue, but the potential benefits to regional and local marine management, including long-term efficiency gains, suggest exploration of the SCEA/CEA concept and approach are warranted.

\section{Conclusion}

The drive to extract greater economic returns from the oceans and the degraded state of many marine ecosystems makes progress in managing cumulative effects essential. This paper argues that cumulative effects assessment is a dynamic process and that systemic coherence between CEAs would be a costeffective means of addressing regional and local obligations to account for cumulative effects. However, to be meaningful in a sustainability/resilience sense, CEAs need to account for complex adaptive systems characteristics. Meeting legal obligations related to CEA requires coherence between multiple assessments over time, requiring agreement about commonalities, including intent, vocabulary and, where possible, principles for practice. This paper argues that CEA should be structured using social-ecological systems thinking and should work towards measuring the significance of human activities relative to the resilience of valued receptors. Candidate principles are suggested to progress towards harmonised regional CEA practice, where an ongoing SCEA aids marine management and planning by accumulating knowledge from CEAs about system dynamics and cumulative environmental change. Testing this or any approach to coherent CEA requires investigations at different temporal and spatial scales, and on a range of system variables. Given the time pressure to improve CEA, it is necessary to identify when CEA is good enough [19] and to enable a genuinely strategic approach to CEA that balances the desire for precision with awareness of the uncertainties and risks involved in managing complex social-ecological systems. 


\section{Acknowledgements}

We thank the two anonymous reviewers for their constructive comments, which strengthened and improved the paper.

EAW is funded through a NERC Industrial CASE studentship (NE/L009668/1) with support from Cefas Divisional Funding.

SNRB and EAW are supported by the Department for Environment, Food and Rural Affairs through the MINERVA project (ME5213). Additional funding provided under the Cefas Seedcorn initiative.

SRJ is part funded through EPSRC/ESRC International Centre for Infrastructure Futures (ICIF) grant (EP/K012347/1).

ABG is supported by PANGALIA Environmental.

No new data were generated during the course of this study.

\section{References}

[1] C. Folke, R. Biggs, A. V. Norström, B. Reyers, J. Rockström, Social-ecological resilience and biosphere-based sustainability science, Ecol. Soc. 21 (2016). doi:10.5751/ES-08748-210341.

[2] J. Wu, Landscape sustainability science: Ecosystem services and human well-being in changing landscapes, Landsc. Ecol. 28 (2013) 999-1023. doi:10.1007/s10980-013-9894-9.

[3] H. Spaling, Cumulative Effects Assessment: Concepts and Principles, 9165 (1994) 37-41.

[4] F.C. Jones, Cumulative effects assessment: theoretical underpinnings and big problems., Environ. Rev. 24 (2016) 187-204. doi:10.1139/er-2015-0073.

[5] E.A. Willsteed, A.B. Gill, S.N.R. Birchenough, S. Jude, Assessing the cumulative environmental effects of marine renewable energy developments: Establishing common ground, Sci. Total Environ. 577 (2016) 19-32. doi:10.1016/j.scitotenv.2016.10.152.

[6] G. Hegmann, G.A.T. Yarranton, Alchemy to reason: Effective use of Cumulative Effects Assessment in resource management, Environ. Impact Assess. Rev. 31 (2011) 484-490. doi:10.1016/j.eiar.2011.01.011.

[7] P.N. Duinker, E.L. Burbidge, S.R. Boardley, L.A. Greig, Scientific Dimensions of Cumulative Effects Assessment: Toward Improvements in Guidance for Practice, Environ. Rev. 52 (2012) 121029052013006. doi:10.1139/er-2012-0035.

[8] C.J. Brown, M.I. Saunders, H.P. Possingham, A.J. Richardson, Interactions between global and local stressors of ecosystems determine management effectiveness in cumulative impact mapping, Divers. Distrib. 20 (2014) 538-546. doi:10.1111/ddi.12159.

[9] N. Teichert, A. Borja, G. Chust, A. Uriarte, M. Lepage, Restoring fish ecological quality in estuaries: Implication of interactive and cumulative effects among anthropogenic stressors, Sci. Total Environ. 542 (2016) 383-393. doi:10.1016/j.scitotenv.2015.10.068.

[10] A.D. Judd, T. Backhaus, F. Goodsir, An effective set of principles for practical implementation of marine cumulative effects assessment, Environ. Sci. Policy. 54 (2015) 254-262. 
doi:10.1016/j.envsci.2015.07.008.

[11] H. Segner, M. Schmitt-Jansen, S. Sabater, Assessing the Impact of Multiple Stressors on Aquatic Biota: The Receptor's Side Matters, Envirnmental Sci. Technol. 48 (2014) 7690-7696. doi:dx.doi.org/10.1021/es405082t.

[12] S. Levin, T. Xepapadeas, A.S. Crepin, J. Norberg, A. De Zeeuw, C. Folke, T. Hughes, K. Arrow, S. Barrett, G. Daily, P. Ehrlich, N. Kautsky, K.G. Maler, S. Polasky, M. Troell, J.R. Vincent, B. Walker, Social-ecological systems as complex adaptive systems: Modeling and policy implications, Environ. Dev. Econ. 18 (2013) 111-132. doi:10.1017/S1355770X12000460.

[13] P.N. Duinker, L.A. Greig, The impotence of cumulative effects assessment in Canada: Ailments and ideas for redeployment, Environ. Manage. 37 (2006) 153-161. doi:10.1007/s00267-004-02405 .

[14] E.E. Hodgson, B.S. Halpern, Investigating cumulative effects across ecological scales, Conserv. Biol. (2018). doi:10.1111/cobi.13125.

[15] H. Sithole, T.T. Cockerill, K.J. Hughes, D.B. Ingham, L. Ma, R.T.J. Porter, M. Pourkashanian, Developing an optimal electricity generation mix for the UK 2050 future, Energy. 100 (2016) 363-373. doi:10.1016/j.energy.2016.01.077.

[16] M. Elliott, Marine science and management means tackling exogenic unmanaged pressures and endogenic managed pressures - A numbered guide, Mar. Pollut. Bull. 62 (2011) 651-655. doi:10.1016/j.marpolbul.2010.11.033.

[17] C. Folke, Resilience ( Republished ), Ecol. Soc. 21 (2016).

[18] C.S. Holling, Resilience and Stability of Ecological Systems, Annu. Rev. Ecol. Syst. 4 (1973) 123. doi:10.1146/annurev.es.04.110173.000245.

[19] R. Therivel, B. Ross, Cumulative effects assessment: Does scale matter?, Environ. Impact Assess. Rev. 27 (2007) 365-385. doi:10.1016/j.eiar.2007.02.001.

[20] E.A. Willsteed, S. Jude, A.B. Gill, S.N.R. Birchenough, Obligations and aspirations: A critical evaluation of offshore wind farm cumulative impact assessments, Renew. Sustain. Energy Rev. (2018). doi:10.1016/j.rser.2017.08.079.

[21] H. Österblom, B.I. Crona, C. Folke, M. Nyström, M. Troell, Marine Ecosystem Science on an Intertwined Planet, Ecosystems. (2016) 1-8. doi:10.1007/s10021-016-9998-6.

[22] B.S. Halpern, S. Walbridge, K. Selkoe, C. V Kappel, F. Micheli, C. D’ Agrosa, J.F. Bruno, K.S. Casey, C. Ebert, H.E. Fox, R. Fujita, D. Heinemann, H.S. Lenihan, E.M.P. Madin, M.T. Perry, E.R. Selig, M. Spalding, R. Steneck, R. Watson, A global map of human impact on marine ecosystems., Science. 319 (2008) 948-52. doi:10.1126/science.1149345.

[23] E. Ostrom, A General Framework for Analyzing Sustainability of Social-Ecological Systems, Science (80-. ). 325 (2009) 419-422.

[24] C.M. Duarte, A. Borja, J. Carstensen, M. Elliott, D. Krause-Jensen, N. Marbà, Paradigms in the Recovery of Estuarine and Coastal Ecosystems, Estuaries and Coasts. 38 (2015) 1202-1212. doi:10.1007/s12237-013-9750-9.

[25] A.M. Knights, R.S. Koss, L.A. Robinson, Identifying common pressure pathways from a complex network of human activities to support ecosystem-based management, Ecol. Appl. 23 (2013) 755765. doi:10.1890/12-1137.1. 
[26] A. Gasparatos, M. El-Haram, M. Horner, The argument against a reductionist approach for measuring sustainable development performance and the need for methodological pluralism, Account. Forum. 33 (2009) 245-256. doi:10.1016/j.accfor.2008.07.006.

[27] C.R. Binder, P.W.G. Bots, J. Hinkel, C. Pahl-Wostl, Comparison of Frameworks for Analyzing Social- ecological Systems Comparison of Frameworks for Analyzing Social-ecological Systems, Ecol. Soc. 18 (2013). doi:10.5751/ES-05551-180426.

[28] X. Basurto, S. Gelcich, E. Ostrom, The social-ecological system framework as a knowledge classificatory system for benthic small-scale fisheries, Glob. Environ. Chang. 23 (2013) 13661380. doi:10.1016/j.gloenvcha.2013.08.001.

[29] S. Partelow, C. Boda, A modified diagnostic social-ecological system framework for lobster fisheries: Case implementation and sustainability assessment in Southern California, Ocean Coast. Manag. 114 (2015) 204-217. doi:10.1016/j.ocecoaman.2015.06.022.

[30] M.D. McGinnis, E. Ostrom, Social-ecological system framework: Initial changes and continuing challenges, Ecol. Soc. 19 (2014). doi:10.5751/ES-06387-190230.

[31] G. Epstein, J.M. Vogt, S.K. Mincey, M. Cox, B. Fischer, Missing ecology: Integrating ecological perspectives with the social-ecological system framework, Int. J. Commons. 7 (2013) 432-453. doi:10.18352/ijc. 371 .

[32] J. Hinkel, P.W.G. Bots, M. Schlüter, Enhancing the Ostrom social-ecological system framework through formalization, Ecol. Soc. 19 (2014). doi:10.5751/ES-06475-190351.

[33] R.J. Standish, R.J. Hobbs, M.M. Mayfield, B.T. Bestelmeyer, K.N. Suding, L.L. Battaglia, V. Eviner, C. V. Hawkes, V.M. Temperton, V.A. Cramer, J.A. Harris, J.L. Funk, P.A. Thomas, Resilience in ecology: Abstraction, distraction, or where the action is?, Biol. Conserv. 177 (2014) 43-51. doi:10.1016/j.biocon.2014.06.008.

[34] G.S. Cumming, G.D. Peterson, Unifying Research on Social-Ecological Resilience and Collapse, Trends Ecol. Evol. 32 (2017) 695-713. doi:10.1016/j.tree.2017.06.014.

[35] B. Walker, C.S. Holling, S.R. Carpenter, A. Kinzig, Resilience, Adaptability and Transformability in Social - ecological Systems, Ecol. Soc. 9 (2004) 5. doi:10.1103/PhysRevLett.95.258101.

[36] A.J. Hobday, Sliding baselines and shuffling species: Implications of climate change for marine conservation, Mar. Ecol. 32 (2011) 392-403. doi:10.1111/j.1439-0485.2011.00459.x.

[37] S. Carpenter, B. Walker, J.M. Anderies, N. Abel, From Metaphor to Measurement: Resilience of What to What?, Ecosystems. 4 (2001) 765-781. doi:10.1007/s10021-001-0045-9.

[38] A.E. Quinlan, M. Berbés-Blázquez, L.J. Haider, G.D. Peterson, Measuring and assessing resilience: broadening understanding through multiple disciplinary perspectives, J. Appl. Ecol. 53 (2016) 677-687. doi:10.1111/1365-2664.12550.

[39] S. Pasquaud, A. Courrat, V.F. Fonseca, R. Gamito, C.I. Gonçalves, J. Lobry, M. Lepage, M.J. Costa, H. Cabral, Strength and time lag of relationships between human pressures and fish-based metrics used to assess ecological quality of estuarine systems, Estuar. Coast. Shelf Sci. 134 (2013) 119-127. doi:10.1016/j.ecss.2013.02.002.

[40] L.J. Gilarranz, C. Mora, J. Bascompte, Anthropogenic effects are associated with a lower persistence of marine food webs, Nat. Commun. 7 (2016) 10737. doi:10.1038/ncomms10737.

[41] I. Rombouts, G. Beaugrand, X. Fizzala, F. Gaill, S.P.R. Greenstreet, S. Lamare, F. Le Loc’H, A. 
McQuatters-Gollop, B. Mialet, N. Niquil, J. Percelay, F. Renaud, A.G. Rossberg, J.P. F??ral, Food web indicators under the Marine Strategy Framework Directive: From complexity to simplicity?, Ecol. Indic. 29 (2013) 246-254. doi:10.1016/j.ecolind.2012.12.021.

[42] I. Donohue, H. Hillebrand, J.M. Montoya, O.L. Petchey, S.L. Pimm, M.S. Fowler, K. Healy, A.L. Jackson, M. Lurgi, D. McClean, N.E. O'Connor, E.J. O’Gorman, Q. Yang, F. Adler, Navigating the complexity of ecological stability, Ecol. Lett. 19 (2016) 1172-1185. doi:10.1111/ele.12648.

[43] S.A. Levin, The Problem of Pattern and Scale in Ecology: The Robert H. MacArthur Award Lecture Author(s): Simon A. Levin Source:, Ecology. 73 (1992) 1943-1967. doi:doi:10.2307/1941447.

[44] M.G. Dubé, Cumulative effect assessment in Canada: A regional framework for aquatic ecosystems, Environ. Impact Assess. Rev. 23 (2003) 723-745. doi:10.1016/S01959255(03)00113-6.

[45] M.M. Foley, L.A. Mease, R.G. Martone, E.E. Prahler, T.H. Morrison, C.C. Murray, D. Wojcik, The challenges and opportunities in cumulative effects assessment, Environ. Impact Assess. Rev. 62 (2017) 122-134. doi:10.1016/j.eiar.2016.06.008.

[46] M.G. Dubé, P.N. Duinker, L. Greig, M. Carver, M. Servos, M. McMaster, B. Noble, H. Schreier, L. Jackson, K.R. Munkittrick, A framework for assessing cumulative effects in watersheds: an introduction to Canadian case studies., Integr. Environ. Assess. Manag. 9 (2013) 363-9. doi:10.1002/ieam.1418.

[47] J. Lonsdale, K. Weston, S. Blake, R. Edwards, M. Elliott, The Amended European Environmental Impact Assessment Directive: UK marine experience and recommendations, Ocean Coast. Manag. 148 (2017) 131-142. doi:10.1016/j.ocecoaman.2017.07.021.

[48] A.J. Sinclair, M. Doelle, P.N. Duinker, Looking up, down, and sideways: Reconceiving cumulative effects assessment as a mindset, Environ. Impact Assess. Rev. 62 (2017) 183-194. doi:10.1016/j.eiar.2016.04.007.

[49] V. Stelzenmüller, M. Coll, A.D. Mazaris, S. Giakoumi, S. Katsanevakis, M.E. Portman, R. Degen, P. Mackelworth, A. Gimpel, P.G. Albano, V. Almpanidou, J. Claudet, F. Essl, T. Evagelopoulos, J.J. Heymans, T. Genov, S. Kark, F. Micheli, M. Grazia, G. Rilov, B. Rumes, A risk-based approach to cumulative effect assessments for marine management, Sci. Total Environ. 612 (2018) 1132-1140. doi:10.1016/j.scitotenv.2017.08.289.

[50] L.H. MacDonald, Evaluating and managing cumulative effects: Process and constraints, Environ. Manage. 26 (2000) 299-315. doi:10.1007/s002670010088.

[51] D.J.C. Skinner, S.A. Rocks, S.J.T. Pollard, G.H. Drew, Identifying Uncertainty in Environmental Risk Assessments: The Development of a Novel Typology and Its Implications for Risk Characterization, Hum. Ecol. Risk Assess. An Int. J. 20 (2014) 607-640. doi:10.1080/10807039.2013.779899.

[52] M. Ball, G. Somers, J.E. Wilson, R. Tanna, C. Chung, D.C. Duro, N. Seitz, Scale, assessment components, and reference conditions: Issues for cumulative effects assessment in Canadian watersheds, Integr. Environ. Assess. Manag. 9 (2013) 370-9. doi:10.1002/ieam.1332.

[53] W.N. Probst, V. Stelzenmuller, A benchmarking and assessment framework to operationalise ecological indicators based on time series analysis, Ecol. Indic. 55 (2015) 94-106. doi:10.1016/j.ecolind.2015.02.035.

[54] R. Froese, H. Winker, G. Coro, N. Demirel, A.C. Tsikliras, D. Dimarchopoulou, G. Scarcella, 
W.N. Probst, M. Dureuil, D. Pauly, A new approach for estimating stock status from length frequency data, (2018). doi:10.1093/icesjms/fsy078.

[55] P.M. Groffman, J.S. Baron, T. Blett, A.J. Gold, I. Goodman, L.H. Gunderson, B.M. Levinson, M.A. Palmer, H.W. Paerl, G.D. Peterson, N.L. Poff, D.W. Rejeski, J.F. Reynolds, M.G. Turner, K.C. Weathers, J. Wiens, Ecological thresholds: The key to successful environmental management or an important concept with no practical application?, Ecosystems. 9 (2006) 1-13. doi:10.1007/s10021-003-0142-z.

[56] M. Coll, J. Steenbeek, J. Sole, I. Palomera, V. Christensen, Modelling the cumulative spatialtemporal effects of environmental drivers and fishing in a NW Mediterranean marine ecosystem, Ecol. Modell. 331 (2016) 100-114. doi:10.1016/j.ecolmodel.2016.03.020.

[57] R. Muthukrishnan, P. Fong, Multiple anthropogenic stressors exert complex, interactive effects on a coral reef community, Coral Reefs. 33 (2014) 911-921. doi:10.1007/s00338-014-1199-1.

[58] S.F. Thrush, J.E. Hewitt, S. Parkes, A.M. Lohrer, C. Pilditch, S.A. Woodin, D.S. Wethey, M. Chiantore, V. Asnaghi, S. De Juan, C. Kraan, I. Rodil, C. Savage, C. Van Colen, Experimenting with ecosystem interaction networks in search of threshold potentials in real-world marine ecosystems, Ecology. 95 (2014) 1451-1457.

[59] C.K. Feld, P. Segurado, C. Gutiérrez-cánovas, Analysing the impact of multiple stressors in aquatic biomonitoring data : a cookbook with applications in R, Sci. Total Environ. (2016). doi:10.1016/j.scitotenv.2016.06.243.

[60] Z.A. Doubleday, A.R. Jones, M.R. Deveney, T.M. Ward, B.M. Gillanders, Eight habitats, 38 threats and 55 experts: Assessing ecological risk in a multi-use marine region, PLoS One. 12 (2017) 1-15. doi:10.1371/journal.pone.0177393.

[61] P.N. Duinker, L.A. Greig, Scenario analysis in environmental impact assessment: Improving explorations of the future, Environ. Impact Assess. Rev. 27 (2007) 206-219. doi:10.1016/j.eiar.2006.11.001.

[62] T. Blenckner, A. Kannen, A. Barausse, C. Fischer, J.J. Heymans, T. Luisetti, V. Todorova, M. Valman, L. Mee, Past and future challenges in managing European seas, Ecol. Soc. 20 (2015) 40. doi:10.5751/ES-07246-200140.

[63] L.R. Harris, M.E. Watts, R. Nel, D.S. Schoeman, H.P. Possingham, Using multivariate statistics to explore trade-offs among spatial planning scenarios, J. Appl. Ecol. 51 (2014) 1504-1514. doi:10.1111/1365-2664.12345. 